\title{
Article
}

\section{Inhibition of Zika Virus by Marine Algae}

\author{
Claudio Cesar Cirne-Santos 1, Caroline de Souza Barros 1,2 , Caio Cesar Richter Nogueira ${ }^{1,2}$, \\ Renata de Mendonça Campos ${ }^{3}$, Valeria Laneuville Teixeira ${ }^{2}$, Davis Fernandes Ferreira ${ }^{3, \&, *}$ and \\ Izabel Christina Nunes de Palmer Paixão 1,\&,*
}
1 Laboratório de Virologia Molecular e Biotecnologia Marinha, Programa de Pós-graduação em Ciências e Biotecnologia, Departamento de Biologia Celular e Molecular, Instituto de Biologia, Universidade Federal Fluminense, Niterói 24.210-150, Brazil; claudiocirne@gmail.com (C.C.C.S.); carolsb.uff@gmail.com (C.S.B.); nogueira.ccr@gmail.com (C.C.R.N); izabeluff@gmail.com (I. C. N. P. P)
2 Laboratório Produtos Naturais de Algas Marinhas (ALGAMAR), Departamento de Biologia Marinha, Instituto de Biologia, Universidade Federal Fluminense, Niterói 24.210-150, Brazil; valerialaneuville@gmail.com (V.L.T.)
3 Instituto de Microbiologia, Departamento de Virologia, Universidade Federal do Rio de Janeiro, Rio de Janeiro 21941-902, Brazil; davisf@micro.ufrj.br (D.F.F.); renatacampos@micro.ufrj.br (R.M.C)
* Correspondence: izabeluff@gmail.com (I. C. N. P. P); Tel.: ++55-21-2629-2280 and davisf@micro.ufrj.br (D.F.F.); Tel.: ++55-21-2560-8344
\& These authors also contributed equally to this work.

\begin{abstract}
For many years marine algae has been subject of numerous researches and as a source of natural products with antiviral activity, such as terpenes, alkaloids and sulphated polysaccharides. However, the anti-Zika virus (ZIKV) potential of algae has not been studied. In this study we evaluated extracts seven species of the three major classes of seaweeds (Phaeophyceae, Chlorophyceae and Rhodophyceae) against ZIKV. All seaweeds tested are native of the Brazilian coast, except for Kappaphycus alvarezii that can be cultivated. ZIKV a mosquito-borne flavivirus, has become a public health problem. In recent years there has been an increase in the number of cases and a strong association between ZIKV outbreak and the spread of cases of Guillain-Barré Syndrome and microcephaly. All seaweed extracts tested in this work inhibits ZIKV replication in a dose-dependent manner. Caulerpa racemosa, Kappaphycus alvarezii and Osmundaria obtusiloba extracts were able to inhibit viral replication at low concentrations with $\mathrm{EC}_{50}$ values ranging from 1.38 to $1.98 \mu \mathrm{g} / \mathrm{mL}$. We observed that $O$. obtusiloba presented a significant virucidal effect. Our results suggest that extracts of $C$. racemosa, K. alvarezii and O. obtusiloba presented very promising results, being excellent candidates for further studies, demonstrating that marine algae are an interesting source for the development of novel anti-ZIKV agents.
\end{abstract}

Keywords: Zika virus; Antiviral; Marine algae

\section{Introduction}

The antiviral potential of marine macroalgae has long been known. Several studies have demonstrated activity of several species of algae against HIV-1[1, 2], HSV-1[3-6], HSV-2[4, 5] and dengue type 2 strains[7]. Thus, marine algae provide a rich source for the discovery of antiviral drugs.

Three major classes of seaweeds, Phaeophyceae (brown algae), Chlorophyceae (green algae) and Rhodophyceae (red seaweeds) were tested against Zika virus (ZIKV) in this work. Being that six species are native of the Brazilian coast (Bryothamnion triquetrum, Canistrocarpus cervicornis, Caulerpa racemosa, Laurencia dendroidea, Osmundaria obtusiloba and Ulva fasciata) and one is coming from cultivation (Kappaphycus alvarezii). K. alvarezii has been used as a financial source generating support for several families specifically on Brazil and is an important source of kappa carrageenan used in industry as gelling and thickening agent, this algae has been farmed successfully in several countries including Brazil [8]. Therefore, it is of great importance to find antiviral activity use for this specie of marine alga, in view of its sustainability of production. 
Arthropod-borne viruses, commonly called arboviruses, normally circulating in nature through biological transmission between susceptible vertebrate hosts and blood-feeding arthropods, such as mosquitoes. Several studies indicate that the most important mosquitoes in this transmission are Aedes aegypti, although there is already much evidence of Aedes albopictus participation in this process $[9,10]$.

Most of the arboviruses that cause disease in humans include alphavirus (Togaviridae: Alphavirus), flaviviruses (Flaviviridae: flaviviruses), bunyaviruses (Bunyaviridae) and some virus Rhabdoviridae and Reoviridae family. Currently 534 viruses listed in the International Catalogue of Arboviruses, of which 214 are known to be, or are probably associated with arthropods, 287 viruses are reported to be possible arboviruses and 33 are considered to be probably or definitely not be arboviruses [11, 12]. In total, 134 of the 534 arboviruses have been reported to cause disease in humans and have a global distribution but the majority circulates in tropical areas, where climatic conditions are favorable for transmission throughout of the year [13, 14].

Birds and rodents are the main hosts and mosquitoes and ticks are most often the vectors for the most important virus. Arboviruses in humans are usually accidental. However, there are several viruses, such as dengue fever, yellow fever, chikungunya and Zika, which mainly infect people starting large outbreaks $[12,15]$.

Zika virus (ZIKV) is a mosquito-borne from genus Flavivirus, family Flaviviridae and cluster with Spondweni serocomplex [16]. Flaviviruses have a positive single-strand RNA genome of approximately 11,000 nucleotides in length. The genome contain long open-reading frame (ORF) that encodes three structural (capsid precursor membrane and envelope) that form viral particles and seven non-structural (NS1, NS2A, NS2B, NS3, NS4A,NS4B, and NS5) proteins. The non-structural proteins participate in viral replication, virion assembly, and evasion of host immune response [17].The infection in humans produces a self-limiting acute febrile illnesses with fever, headache, myalgia and rash, very similar to other arboviruses like Dengue Virus and Chikungunya. Therefore, in regions where one or more arbovirus are detected, ZIKV could circulated causing misleading and being sub-notified.[16, 18].

After virus first detection, in 1947 during a yellow fever surveillance program in Uganda, few reports of the disease were done, until 2007 when there was a large outbreak in Yap Island Federal Sate of Micronesia [19, 20]. In October of 2013, a big outbreak ocurrs at French Polynesia where 396 laboratory confirmed cases was reported. Until now, for ZIKV two main distinct geographic lineages were described (African and Asian)[21, 22].

A substantial proportion of ZIKV infections are subclinical, when clinical symptoms occur the disease produced is considered moderate and self-limited. Although, studies describes a strong association between ZIKV outbreak and the increased numbers of cases of Guillain Barre Syndrome (GBS) in French Polynesia, pointing out a first complication resulting of a ZIKV infection [23, 24]. Studies point to strong evidence of cases of microcephaly when women are infected during pregnancy. These facts have been guided by several evidences that have made this outbreak differentiated and carried great fear to the population of pregnant women[25, 26]. Other associated factors such as hyperglycemia among other malignancies are clear demonstrations of a potent morbidity of this virus [27].

On May 15, 2015, the Ministry of Health of Brazil confirmed the ZIKV circulation in the country after ZIKV ID in 16 samples (eight of Bahia and eight Rio Grande do Norte) by the National Reference Laboratory. The symptoms that have been described are the most common, arthralgia, edema of the extremities, slight fever, headache, retro-orbital pain, conjunctival hyperemia and maculopapular rashes often spreading down the face to the limbs and often itchy, dizziness, myalgia and digestive disorder.[28, 29].

There is no vaccine or specific antiviral therapy for the prevention or treatment of infections by ZIKV. A recent study identified the viral polymerase inhibitor 7DMA as an inhibitor of in vitro ZIKV replication and in virus-infected mice significantly reduced viremia and delayed virus-induced morbidity and mortality [30]. Deng, et al. [31] also showed that an adenosine analog has in vitro and in vivo activity against ZIKV. 
Based on all the clear evidences that have been observed in the literature, determining the strong associations to different gravity frames for this infection and being eminent the search for immediate solutions to contribute to its control, the objective of our work is to look for antivirals alternatives to the reduction of the morbidity and mortality of the ZIKV infection, contributing to a decrease in the number of infected persons and possible consecutive outbreaks.

\section{Results}

\subsection{Cytotoxicityand effect of the extracts on the ZIKV replication in VERO cells.}

The cytotoxicity $\left(\mathrm{CC}_{50}\right)$ of the extracts from the algae collected in the Brazilian coast was assessed by MTT (3-(4,5-dimethylthiazol-2y)-2,5d iphenyl tetrazolium bromide (Sigma-Aldrich) as previously described [32] with some modification. The results in Table 1 showed that $C$. racemosa extract present the best $\mathrm{CC}_{50}$ with value of $732 \mu \mathrm{g} / \mathrm{mL}$, followed by O. obtusiloba $(525 \mu \mathrm{g} / \mathrm{mL})$ and B. triquetrum (400 $\mu \mathrm{g} / \mathrm{mL})$. Subsequently, we evaluated the antiviral activity of the extracts. For these analyzes we tested different concentrations of the extracts starting from a concentration with inhibitory potential of $50 \mu \mathrm{g} / \mathrm{mL}$ declining progressively. We observed that all the substances were able to inhibit the replication of ZIKV in a dose-dependent manner by inhibiting plaque formation (Figure 1). On the other hand, only K. alvarezii, C. racemosa and O. obtusiloba extracts were able to inhibit above $90 \%$ ZIKV replication presenting EC $\mathrm{E}_{50}$ in low concentrations with EC 50 values of $1.38,1.98$ and $1.82 \mu \mathrm{g} / \mathrm{mL}$, respectively. Based on these data, we evaluated the Selectivity Index (SI) that represents the degree of reliability of the extracts for possible future use and that has the relationship between the $\mathrm{CC}_{50}$ and the $\mathrm{EC}_{50}$, corroborating the perspectives that the three extracts with the lowest $\mathrm{EC}_{50}$ also had a higher index of selectivity. C. racemosa presented a higher index 369.7, followed by K. alvarezii 306.5 and after O. obtusiloba with SI of 288 (table 1).

Table 1. Cytotoxicity $\left(\mathrm{CC}_{50}\right)$, anti-ZIKV profile $\left(\mathrm{EC}_{50}\right)$ and selectivity index (SI) of seven seaweeds crude extracts.

\begin{tabular}{cccc}
\hline Crude extracts & CC $_{50^{\mathbf{a}}}$ & EC $_{50^{\mathbf{b}}}$ & SIc $^{\mathbf{c}}$ \\
\hline C. cervicornis & $438 \mu \mathrm{g} / \mathrm{mL}$ & $2.2 \mu \mathrm{g} / \mathrm{mL}$ & 199 \\
C. racemosa & $732 \mu \mathrm{g} / \mathrm{mL}$ & $1.98 \mu \mathrm{g} / \mathrm{mL}$ & 369,7 \\
L. dendroidea & $178 \mu \mathrm{g} / \mathrm{mL}$ & $12.95 \mu \mathrm{g} / \mathrm{mL}$ & 13,7 \\
U. fasciata & $245 \mu \mathrm{g} / \mathrm{mL}$ & $8.1 \mu \mathrm{g} / \mathrm{mL}$ & 30.2 \\
O. obtusiloba & $525 \mu \mathrm{g} / \mathrm{mL}$ & $1.82 \mu \mathrm{g} / \mathrm{mL}$ & 288 \\
K. alvarezii & $423 \mu \mathrm{g} / \mathrm{mL}$ & $1.38 \mu \mathrm{g} / \mathrm{mL}$ & 306,5 \\
B. triquetrum & $400 \mu \mathrm{g} / \mathrm{mL}$ & $2.85 \mu \mathrm{g} / \mathrm{mL}$ & 140,35 \\
\hline
\end{tabular}

The mean values \pm standard deviations are representative of three independent experiments. ${ }^{a}$ Concentration that reduced $50 \%$ cytotoxic concentration when compared to untreated controls. ${ }^{b}$ Concentration that reduced $50 \%$ of ZIKV replication when compared to infected controls. c Selectivity index was defined as the ratio between $\mathrm{CC}_{50}$ and $\mathrm{EC}_{50}$ and represents the safety for in vitro assays. 


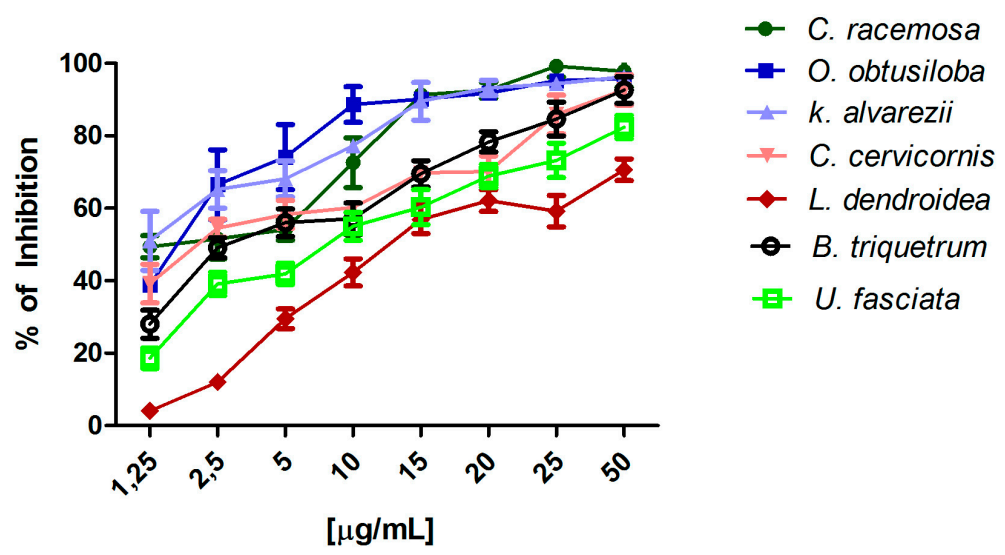

Figure 1. Effect of seven seaweeds crude extracts on ZIKV replication in different concentration $1.25 \mu \mathrm{M}, 2.5 \mu \mathrm{M}, 5 \mu \mathrm{M}, 10 \mu \mathrm{M}, 15 \mu \mathrm{M}, 20 \mu \mathrm{M}, 25 \mu \mathrm{M}$ and $50 \mu \mathrm{M}$.

\subsection{Virucidal effect}

The virucidal activity from the extracts of C. racemosa, K. alvarezii and O. obtusiloba, which presented the best SI values, was evaluated against ZIKV. The viral suspension was maintained with different concentrations of the extracts $(2.5,5$ and $10 \mu \mathrm{M})$ during 2 hours and after was added in Vero cell culture. The final concentration of the compound was low and had no effect on viral replication normally. The results showed that O. obtusiloba was the only substance that presented this virucidal activity in a significantly intense way. The figure 2 shows that $10 \mu \mathrm{M}$ concentration of this extract was able to inhibit around $80 \%$ of the ZIKV replication. The others extracts did not present good inhibitory potential for this mechanism.

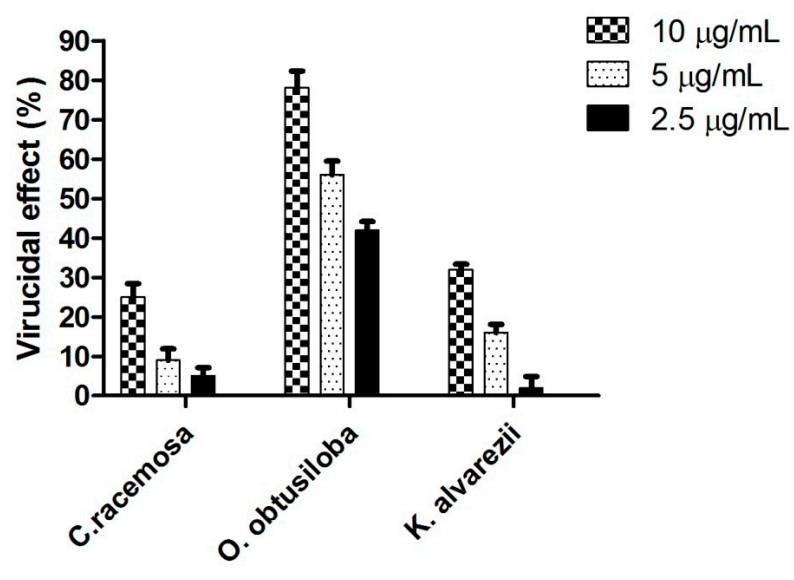

Figure 2. Effect of C. racemosa, O. obtusiloba and K. alvarezii crude extracts on infectivity of ZIKV. Vero cells were infected with ZIKV on MOI of 0.1, the results were evaluated by plaque assay. Error bars indicate the standard deviation and experiments were performed in triplicate.

\subsection{Time of Drug Addition}

To identify the step at which viral replication might be inhibited we perform the time of addition experiment with the compounds administered at $3,2 \mu \mathrm{g} / \mathrm{mL}$ and 1 hours before infection, time 0 (immediately of virus added) and 1, 2, and 3 hours after infection and Ribavirin at $5 \mu \mathrm{M}$ was used as a control. As it is possible to observe in figure 3 that in time 0 all extracts were able to inhibit above $80 \%$ of viral replication. O. obtusiloba and Ribavirin maintained the inhibitory effect on the others 
times. On the other hand, C. racemose and $K$. alvarezii present a reduction on the ZIKV replication in times 1 and 3 post infection, respectively.

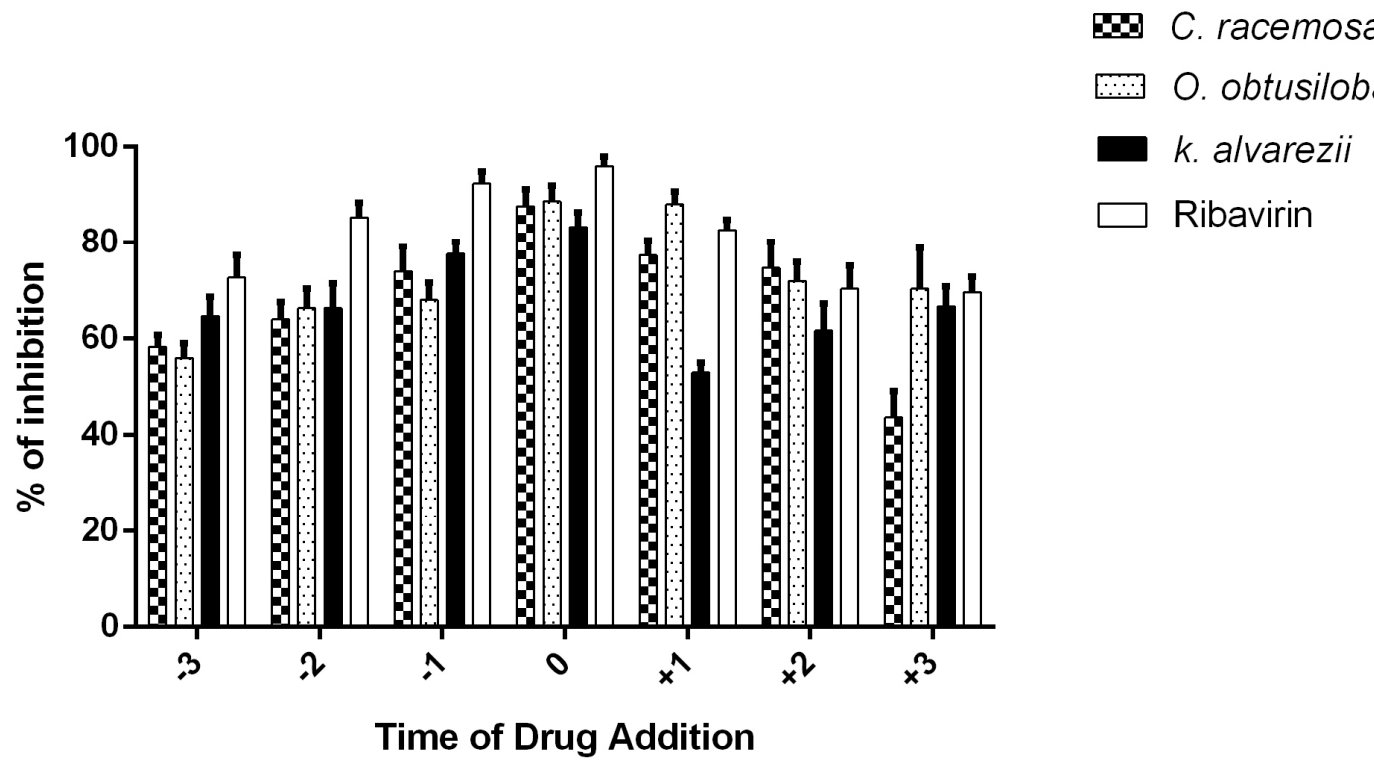

Figure 3. Time of drug addition studies with C. racemosa, O. obtusiloba and K. alvarezii crude extracts on ZIKV replication. Vero cells were infected with ZIKV on MOI of 0.1 following each treatment (before the infection, $-3 \mathrm{~h},-2 \mathrm{~h}$ and $-1 \mathrm{~h}$; during the infection, $0 \mathrm{~h}$; and after the infection, +1 , +2 and +3 ), the results were evaluated by plaque assay. Error bars indicate the standard deviation and experiments were performed in triplicate. Ribavirin $(5 \mu \mathrm{M})$ was used as a positive control.

\section{Discussion}

In this study our group was able to demonstrate the antiviral activity of extracts derived from marine algae on the replication of ZIKV, and we can clearly observe the important inhibitory potential of these extracts in a dose-dependent manner.

The antiviral activities of natural compounds are well known and still under constant study to increase the numbers of drugs available to reduce the morbidity and mortality of many infections, especially for those in which no vaccines are available [33, 34].

There are few studies demonstrating the effect of natural compounds on ZIKV infection and some groups have sought to understand the immunopathogenicity of the virus in an attempt to explain possible associations with severe forms such as microcephaly and Guillain-Barré syndrome [23-26]. In this study our results demonstrate that C. racemosa, K. alvarezii and O. obtusiloba extracts were able to inhibit viral replication significantly and at low concentrations of the extracts with EC 50 values ranging from 1.38 to $1.98 \mu \mathrm{g} / \mathrm{mL}$. Some studies have already shown the potential of these algae against other viruses. Studies with $C$. racemosa showed activity against Bovine viral diarrhea virus (BVDV) [35] and HSV-1[4], as well O. obtusiloba also exhibits anti-HSV-1 activity described [36]. Hirayama, et al. [37] study showed that the lectins from the cultivated alga K. alvarezii inhibit the HIV virus entry to the host cells. K. alvarezii has been reported in several articles with activities for different microorganisms in addition to other activities such as anti-oxidant [38], antimicrobial [39], antiinflamatory, antidiabetic [40]. We must also take sustainability into account with the knowledge that the cultivation of these algae is highly differentiated.

We observed that O. obtusiloba presented a significant virucidal effect, inhibiting viral replication more than $80 \%$ in the concentration of $10 \mu \mathrm{M}$, leading to the belief that this may be an excellent model of action to using as a preventing treatment, considering the effect directly on the virus particle. This effect have great importance in view of the possible sexual transmission of ZIKV [41]. Based on these 
findings could take into account the use of this extract as a preventive method with the pharmaceutical presentation of a microbicide. Microbicides represent an important strategy with clear potential for preventing the transmission of virus through sexual intercourse [42].

Interestingly, we performed the studies of inhibition of viral replication in different phases and using the concentration of $\mathrm{EC}_{50}$. Time of addition studies of the extracts demonstrated that in time 0 all extracts were able to inhibit above $80 \%$ of viral replication and O. obtusiloba maintained the inhibitory effect on the others times. While, C. racemose and K. alvarezii present a reduction the ZIKV replication in times 1 and 3 post infection, respectively. This data suggests the potential of $O$. obtusiloba as an algae extract candidate for further investigation. Another group in 2016 performed Time of drug addition studies with the viral polymerase inhibitor 7DMA, but without pre-treatment and with post-treatment at different time points up to 24 hours, showing that addition of the compound to infected cells could be delayed until $\sim 10$ hours pi without much loss of antiviral potency [30].

Our findings show that all crude extracts tested showed activity against ZIKV, demonstrating that marine algae are an interesting source for drug discovery and the development of novel antiZIKV agents. Extracts of $C$. racemosa, K. alvarezii and O. obtusiloba presented very promising results, being excellent candidates for further studies with their isolated products to better elucidate their mechanisms of action.

\section{Materials and Methods}

\subsection{Crude extracts obtention}

Native species of macroalgae were collected from Brazilian coast (Bryothamnion triquetrum, Canistrocarpus cervicornis, Caulerpa racemosa, Laurencia dendroidea, Osmundaria obtusiloba and Ulva fasciata). The seaweed Kappaphycus alvarezii was harvested from mariculture located in Paraty, Rio de Janeiro state - Brazil. All algae were washed with local sea water and separated from sediments, epi-phytes, and other associated organisms. Air-dried seaweeds were powdered and exhaustively extracted using different organic solvents, as described in Table 2.

Table 2: Brazilian species of seaweed collected and extraction mode.

\begin{tabular}{|c|c|c|}
\hline Species & Sampling Site & Extraction solvents \\
\hline $\begin{array}{l}\text { Bryothamnion triquetrum } \\
\text { (S.G.Gmelin) M.Howe }\end{array}$ & $\begin{array}{l}\text { Atol das Rocas reef, Rio } \\
\text { Grande do Norte State (lat. } \\
03^{\circ} 51^{\prime} 03^{\prime \prime} \text {, long. } 33^{\circ} 40^{\prime} 29^{\prime \prime} \text { ) }\end{array}$ & Dichloromethane \\
\hline $\begin{array}{c}\text { Canistrocarpus cervicornis } \\
\text { (Kützing) De Paula\& De } \\
\text { Clerck }\end{array}$ & $\begin{array}{l}\text { Baía da Ribeira, Angra dos } \\
\text { Reis, Rio de Janeiro State (lat. } \\
22^{\circ} 98^{\prime} 33^{\prime \prime} \text {, long. } 44^{\circ} 38^{\prime} 33^{\prime \prime} \text { ) }\end{array}$ & Dichloromethane \\
\hline $\begin{array}{c}\text { Caulerpa racemosa (Forsskål) } \\
\text { J.Agardh }\end{array}$ & $\begin{array}{l}\text { Baía da Ribeira, Angra dos } \\
\text { Reis, Rio de Janeiro State (lat. } \\
22^{\circ} 98^{\prime} 33^{\prime \prime} \text {, long. } 44^{\circ} 38^{\prime} 33^{\prime \prime} \text { ) }\end{array}$ & Acetone \\
\hline $\begin{array}{c}\text { Kappaphycus alvarezii (Doty) } \\
\text { Doty ex P.C.Silva }\end{array}$ & $\begin{array}{l}\text { Praia Grande, Paraty, Rio de } \\
\text { Janeiro State (lat. } 23^{\circ} 16^{\prime} 15^{\prime \prime} \\
\left.\text { long. } 44^{\circ} 34^{\prime} 48^{\prime \prime}\right)\end{array}$ & Ethanol \\
\hline Laurencia dendroidea J.Agardh & $\begin{array}{c}\text { Orla Bardot, Armação de } \\
\text { Búzios, Rio de Janeiro State } \\
\text { (lat. } 22^{\circ} 05^{\prime} 03^{\prime \prime} \text {, long. } 41^{\circ} 53^{\prime} \\
\left.01^{\prime \prime}\right)\end{array}$ & Hexane \\
\hline
\end{tabular}


Osmundaria obtusiloba

(C.Agardh) R.E.Norris

Ulva fasciata Delile
Rasa Beach, Armação de

Búzios, Rio de Janeiro State

(lat. 22。 $45^{\prime} 40^{\prime \prime}$, long. $41^{\circ} 54^{\prime}$

$32 "$ )

Itaipú Beach, Niterói, Rio de

Janeiro State (lat. 22 58'26", long. $\left.43^{\circ} 02^{\prime} 46^{\prime \prime}\right)$

\subsection{Cells and Virus}

Vero cells (African green monkey kidney) were grown in Eagle's minimum essential medium (MEM) (GIBCO) supplemented with 5\% calf serum. For plaquing medium (PM), methylcellulose was added at a final concentration of $1 \%$. The C6/36 mosquito cell line from Aedes albopictus, adapted to grow at $28^{\circ} \mathrm{C}$, was cultured in L-15 Medium (Leibovitz) supplemented with $0.5 \%$ tryptose phosphate broth, $0.03 \%$ glutamine, $1 \%$ MEM non-essential amino acids solution and $5 \%$ fetal bovine serum.

\subsection{Cellular cytotoxicity assay}

To assess the cytotoxic effect of the extracts on Vero cells with $90 \%$ confluent in 96 cell plate, the cells were treated at 25,50,100,200, 400 and $800 \mu \mathrm{g} / \mathrm{mL}$ of crude extracts of algae and incubate for 2 to 3 days in DMEM plus $5 \%$ of $\mathrm{FBS}$ at $37^{\circ} \mathrm{C}$ in $\mathrm{CO}_{2}$ incubator. Next, MTT reagent $(5 \mathrm{mg} / \mathrm{mL})$ (Sigma Aldrich), was added after 3 days post drug treatment and incubated for $3 \mathrm{~h}$ at $37^{\circ} \mathrm{C}$. Media was removed, $100 \mu \mathrm{M}$ DMSO was added and cells were incubated at $37^{\circ} \mathrm{C}$ for 15 minutes to dissolve the Formazan crystals as described [32]. The absorbance was measured at $550 \mathrm{~nm}$ using ELISA plate reader. The metabolically active cell percentage was compared with the cells control and cellular cytotoxicity was determined. To validate this experiment, we perform three times by independently form.

\subsection{Plaque reduction assay}

Vero cells were grown in medium DMEM. Next, cells were incubated with ZIKV for $2 \mathrm{~h}$, washed with PBS and a mixture of $2 \%(\mathrm{w} / \mathrm{v})$ carboxymethylcellullose (Sigma Aldrich) and DMEM supplemented with 5\% FCS, $5 \mathrm{mM}$ L-glutamine and $0.20 \%$ sodium bicarbonate were added. Serial dilutions of compounds without overlap medium were done. Cells were fixed with 10\% formaldehyde subsequently stained with $1 \%$ violet crystal, respectively. The infectious virus titer $(\mathrm{PFU} / \mathrm{mL})$ was determined using the following formula: plate count $\times$ dilution factor $\times(1 /$ inoculation volume).

\subsection{Antiviral assay}

Antiviral activity was evaluated using a virus plaque reduction assay. Vero cells were grown in 24-well plates under described conditions and subsequently infected with MOI of 0.1 in the absence or presence of different concentrations of the compounds. After $1 \mathrm{~h}$ of adsorption at $37^{\circ} \mathrm{C}$, residual inoculum was replaced by medium containing $1 \%$ methyl-cellulose and the corresponding dose of each compound. Plaques were counted after 5-10 days of incubation at $37^{\circ} \mathrm{C}$ at $5 \% \mathrm{CO}_{2}$. The inhibitory concentration $50 \%$ (EC50) was calculated as the compound concentration required reducing virus plaques by $50 \%$. All determinations were performed twice and each in triplicate.

\subsection{Viral kinetics and time-of-drug addition studies}

Vero cells were infected with ZIKV at a MOI of 0.1 and incubated for $2 \mathrm{~h}$. After the viruses were removed and the medium was replaced. In addition, $2.5 \mathrm{mg} / \mathrm{mL}$ of C. racemosa, O. obtusiloba and $K$. alvarezii crude extracts at different points of virus replication at 3,2 and 1 hours before infection, time 0 (immediately of virus added) and 1, 2, and 3 hours after infection. These cells were incubated at 5\% 
$\mathrm{CO}_{2}$ atmosphere and $37^{\circ} \mathrm{C}$ for 3 or 5 days. The viral replication was measured by plaque assay perform.

\subsection{Virucidal effect}

A ZIKV suspension containing $5 \times 10^{6} \mathrm{PFU} / \mathrm{mL}$ was incubated with an equal volume of MM with or without different concentrations of C. racemosa, O. obtusiloba and K. alvarezii for $2 \mathrm{~h}$ at $37^{\circ} \mathrm{C}$. Then, the samples were diluted in $\mathrm{MM}$ and the remaining infectivity was titrated by plaque formation. The important point about the extracts is that the sample dilution effectively reduced the drug concentration to be incubated with the cells at least 200-fold to assess that titer reduction was only due to cell-free virion inactivation. The virucidal effect $50 \%$ relative was defining with inactivation by $50 \%$ compared as a control.

\section{Conclusions}

In summary, we here report that extracts from C. racemosa, O. obtusiloba and K. alvarezii have antiZIKV activities showing that $O$. obtusiloba present a significant virucidal effect. Currently, there are no vaccines or specific drugs for prevention and treatment of ZIKV infection. The results obtained encourage further exploration of the antiviral properties of marine extracts as the in vivo studies of the activity in animal models.

Acknowledgments: The authors are grateful to CNPq (Conselho Nacional de Desenvolvimento Científico e Tecnológico) for financial support and for Productivity Fellowships to ICNPP and VLT. VLT also thank the FAPERJ (Fundação de Amparo à Pesquisa do Estado do Rio de Janeiro) for Cientista do Nosso Estado Fellowship. CSB thanks FAPERJ for the PHD fellowship. CCCS thanks CAPES (Coordenação de Aperfeiçoamento de Pessoal de Nível Superior) for the PHD fellowship.

Author Contributions: CCCS, CSB, RCM, DFF, and ICNPP conducted biological (antiviral and virucidal) tests. CSB, CCRN and VLT conducted the extraction and algae identification. CCCS, CSB, CCRN, VLT and ICNPP drafted the manuscript.

Conflicts of Interest: The authors declare no conflict of interest.

\section{References}

1. Barros, C. d. S.; Cirne-Santos, C. C.; Garrido, V.; Barcelos, I.; Stephens, P. R. S.; Giongo, V.; Teixeira, V. L.; de Palmer Paixão, I. C. N., Anti-HIV-1 activity of compounds derived from marine alga Canistrocarpus cervicornis. J. Appl. Phycol. 2015, 1-5.

2. Cirne-Santos, C. C.; Souza, T. M. L.; Teixeira, V. L.; Fontes, C. F. L.; Rebello, M. A.; Castello-Branco, L. R. R.; Abreu, C. M.; Tanuri, A.; Frugulhetti, I. C.; Bou-Habib, D. C., The dolabellane diterpene Dolabelladienetriol is a typical noncompetitive inhibitor of HIV-1 reverse transcriptase enzyme. Antiviral Res. 2008, 77, (1), 6471.

3. Barros, C. S.; Teixeira, V. L.; Paixão, I. C., Seaweeds with anti-herpes simplex virus type 1 activity. J. Appl. Phycol. 2014, 27, 1623-1637.

4. Soares, A. R.; Robaina, M.; Mendes, G. S.; Silva, T. S.; Gestinari, L.; Pamplona, O. S.; Yoneshigue-Valentin, Y.; Kaiser, C. R.; Romanos, M. T. V., Antiviral activity of extracts from Brazilian seaweeds against herpes simplex virus. Rev. Bras. de Farmacogn. 2012, 22, (4), 714-723.

5. Mendes, G. d. S.; Bravin, I. C.; Yoneshigue-Valentin, Y.; Yokoya, N. S.; Romanos, M. T. V., Anti-HSV activity of Hypnea musciformis cultured with different phytohormones. Rev. Bras. de Farmacogn. 2012, 22, (4), 789794.

6. Macedo, N. R. P. V.; Ribeiro, M. S.; Villaça, R. C.; Ferreira, W.; Pinto, A. M.; Teixeira, V. L.; Cirne-Santos, C.; Paixão, I. C.; Giongo, V., Caulerpin as a potential antiviral drug against herpes simplex virus type 1. Rev. Bras. de Farmacogn. 2012, 22, (4), 861-867.

7. Talarico, L. B.; Duarte, M. E.; Zibetti, R. G.; Noseda, M. D.; Damonte, E. B., An algal-derived DL-galactan hybrid is an efficient preventing agent for in vitro dengue virus infection. Planta Med. 2007, 73, (14), 1464-8.

8. Hayashi, L.; de Paula, E. J.; Chow, F., Growth rate and carrageenan analyses in four strains of Kappaphycus alvarezii (Rhodophyta, Gigartinales) farmed in the subtropical waters of São Paulo State, Brazil. J. Appl. Phycol. 2007, 19, (5), 393-399. 
9. Kraemer, M. U.; Sinka, M. E.; Duda, K. A.; Mylne, A. Q.; Shearer, F. M.; Barker, C. M.; Moore, C. G.; Carvalho, R. G.; Coelho, G. E.; Van Bortel, W., The global distribution of the arbovirus vectors Aedes aegypti and Ae. albopictus. Elife 2015, 4, e08347.

10. Calvez, E.; Guillaumot, L.; Millet, L.; Marie, J.; Bossin, H.; Rama, V.; Faamoe, A.; Kilama, S.; Teurlai, M.; Mathieu-Daudé, F., Genetic diversity and phylogeny of Aedes aegypti, the main arbovirus vector in the Pacific. PLoS Negl. Trop. Dis. 2016, 10, (1), e0004374.

11. Iranpour, M.; Moghadam, A. R.; Yazdi, M.; Ande, S. R.; Alizadeh, J.; Wiechec, E.; Lindsay, R.; Drebot, M.; Coombs, K. M.; Ghavami, S., Apoptosis, autophagy and unfolded protein response pathways in Arbovirus replication and pathogenesis. Expert. Rev. Mol. Med. 2016, 18, e1.

12. Gubler, D. J., Human arbovirus infections worldwide. Ann. N. Y. Acad. Sci. 2001, 951, 13-24.

13. Gyawali, N.; Bradbury, R. S.; Taylor-Robinson, A. W., Do neglected Australian arboviruses pose a global epidemic threat? Aust. N. Z. J. Public Health 2016.

14. Tabachnick, W. J., Climate Change and the Arboviruses: Lessons from the Evolution of the Dengue and Yellow Fever Viruses. Annu. Rev. Virol. 2016, 3, (1), 125-145.

15. Weaver, S. C.; Forrester, N. L., Chikungunya: Evolutionary history and recent epidemic spread. Antiviral Res 2015, 120, 32-39.

16. Vorou, R., Zika virus, vectors, reservoirs, amplifying hosts, and their potential to spread worldwide: what we know and what we should investigate urgently. Emerg. Infect. Dis. 2016, 48, 85-90.

17. Lindenbach, B.; Murray, C.; Thiel, H.; Rice, C., Flaviviridae, p 712-746. Fields virology 2013, 1.

18. Tappe, D.; Nachtigall, S.; Kapaun, A.; Schnitzler, P.; Gunther, S.; Schmidt-Chanasit, J., Acute Zika virus infection after travel to Malaysian Borneo, September 2014. Int. J. Infect. Dis. 2015, 21, (5), 911-3.

19. Hamel, R.; Liégeois, F.; Wichit, S.; Pompon, J.; Diop, F.; Talignani, L.; Thomas, F.; Desprès, P.; Yssel, H.; Missé, D., Zika virus: epidemiology, clinical features and host-virus interactions. Microb. Infect. 2016.

20. Faye, O.; Freire, C. C.; Iamarino, A.; Faye, O.; de Oliveira, J. V. C.; Diallo, M.; Zanotto, P. M., Molecular evolution of Zika virus during its emergence in the 20 th century. PLoS Negl. Trop. Dis. 2014, 8, (1), e2636.

21. Kucharski, A. J.; Funk, S.; Eggo, R. M.; Mallet, H.-P.; Edmunds, W. J.; Nilles, E. J., Transmission dynamics of Zika virus in island populations: a modelling analysis of the 2013-14 French Polynesia outbreak. PLoS Negl. Trop. Dis. 2016, 10, (5), e0004726.

22. Musso, D.; Nilles, E.; Cao-Lormeau, V.-M., Rapid spread of emerging Zika virus in the Pacific area. Clin. Microbiol. Infect. 2014, 20, (10), O595-O596.

23. Teixeira, M. G.; da Conceição N. Costa, M.; de Oliveira, W. K.; Nunes, M. L.; Rodrigues, L. C., The Epidemic of Zika Virus-Related Microcephaly in Brazil: Detection, Control, Etiology, and Future Scenarios. Am. J. Public Health 2016, 106, (4), 601-605.

24. Cao-Lormeau, V.-M.; Blake, A.; Mons, S.; Lastère, S.; Roche, C.; Vanhomwegen, J.; Dub, T.; Baudouin, L.; Teissier, A.; Larre, P., Guillain-Barré Syndrome outbreak associated with Zika virus infection in French Polynesia: a case-control study. The Lancet 2016, 387, (10027), 1531-1539.

25. Rodrigues, L. C., Microcephaly and Zika virus infection. The Lancet 2016, 387, (10033), 2070-2072.

26. Mlakar, J.; Korva, M.; Tul, N.; Popović, M.; Poljšak-Prijatelj, M.; Mraz, J.; Kolenc, M.; Resman Rus, K.; Vesnaver Vipotnik, T.; Fabjan Vodušek, V., Zika virus associated with microcephaly. N. Engl. J. Med. 2016, 374, (10), 951-958.

27. Nielsen, K. K.; Bygbjerg, I. C., Zika virus and hyperglycaemia in pregnancy. The Lancet 2016, 387, (10030), 1812.

28. Heukelbach, J.; Alencar, C. H.; Kelvin, A. A.; de Oliveira, W. K.; de Góes Cavalcanti, L. P., Zika virus outbreak in Brazil. J. Infect. Dev. Ctries. 2016, 10, (02), 116-120.

29. Junior, V. L. P.; Luz, K.; Parreira, R.; Ferrinho, P., Zika virus: a review to clinicians. Acta Med. Port. 2015, 28, (6), 760-765.

30. Zmurko, J.; Marques, R. E.; Schols, D.; Verbeken, E.; Kaptein, S. J.; Neyts, J., The Viral Polymerase Inhibitor 7-Deaza-2'-C-Methyladenosine Is a Potent Inhibitor of In Vitro Zika Virus Replication and Delays Disease Progression in a Robust Mouse Infection Model. PLOS Negl. Trop. Dis. 2016, 10, (5), e0004695.

31. Deng, Y. Q.; Zhang, N. N.; Li, C. F.; Tian, M.; Hao, J. N.; Xie, X. P.; Shi, P. Y.; Qin, C. F., Adenosine Analog NITD008 Is a Potent Inhibitor of Zika Virus. Open Forum Infect. Dis. 2016, 3, (4), ofw175.

32. Mosmann, T., Rapid colorimetric assay for cellular growth and survival: application to proliferation and cytotoxicity assays. J Immunol Methods 1983, 65, (1-2), 55-63. 
33. Blunt, J. W.; Copp, B. R.; Keyzers, R. A.; Munro, M. H.; Prinsep, M. R., Marine natural products. Nat. Prod. Rep. 2014, 31, (2), 160-258.

34. Dias, D. A.; Urban, S.; Roessner, U., A historical overview of natural products in drug discovery. Metabolites 2012, 2, (2), 303-336.

35. Pinto, A. M. V.; Leite, J. P. G.; Ferreira, W. J.; Cavalcanti, D. N.; Villaça, R. C.; Giongo, V.; Teixeira, V. L.; Paixão, I. C. N. d. P., Marine natural seaweed products as potential antiviral drugs against bovine viral diarrhea virus. Rev. Bras. de Farmacogn. 2012, 22, (4), 813-817.

36. Santos, M.; Lagrota, M.; Miranda, M.; Yoneshigue-Valentin, Y.; Wigg, M., A screening for the antiviral effect of extracts from Brazilian marine algae against acyclovir resistant herpes simplex virus type 1. Bot. Mar. 1999, 42 , (3), 227-230.

37. Hirayama, M.; Shibata, H.; Imamura, K.; Sakaguchi, T.; Hori, K., High-Mannose Specific Lectin and Its Recombinants from a Carrageenophyta Kappaphycus alvarezii Represent a Potent Anti-HIV Activity Through High-Affinity Binding to the Viral Envelope Glycoprotein gp120. Mar. Biotechnol. 2016, 18, (1), 144160.

38. Kumar, K. S.; Ganesan, K.; Rao, P. S., Antioxidant potential of solvent extracts of Kappaphycus alvarezii (Doty) Doty-An edible seaweed. Food Chem. 2008, 107, (1), 289-295.

39. Venkatesh, R.; Shanthi, S.; Rajapandian, K.; Elamathi, S.; Thenmozhi, S.; Radha, N., Preliminary study on antixanthomonas activity, phytochemical analysis and characterization of antimicrobial compounds from Kappaphycus alvarezii. Asian J. Pharm. Clin. Res. 2011, 4, (3), 46-51.

40. Nagarani, N.; Kamaguru, A., Evaluation of antiinflammatory, antidiabetic, cytotoxic activity of Kappaphycus alvarezii. Int. J. Pharm. Bio. Sci. 2013, 4, 921-929.

41. Towers, S.; Brauer, F.; Castillo-Chavez, C.; Falconar, A. K.; Mubayi, A.; Romero-Vivas, C. M., Estimate of the reproduction number of the 2015 Zika virus outbreak in Barranquilla, Colombia, and estimation of the relative role of sexual transmission. Epidemics 2016, 17, 50-55.

42. Buckheit, R. W.; Watson, K. M.; Morrow, K. M.; Ham, A. S., Development of topical microbicides to prevent the sexual transmission of HIV. Antiviral Res. 2010, 85, (1), 142-158.

(C) 2017 by the authors. Licensee Preprints, Basel, Switzerland. This article is an open access article distributed under the terms and conditions of the Creative Commons by Attribution (CC-BY) license (http://creativecommons.org/licenses/by/4.0/). 